\title{
Effects of political instability on the volatility of Palestinian food prices
}

\author{
Rico Ihle*, Mahmoud Khader El-Jafari ${ }^{* *}$, \\ Stephan von Cramon-Taubadel $* \star \star$
}

DOI: $10.30682 / \mathrm{nm} 1903 \mathrm{e}$

JEL codes: C22, F51, Q11, Q18, Q21

\begin{abstract}
Political instabilities and violent political conflict have in recent years risen substantially throughout the world. Especially in the Middle East and North Africa they have grown to decisive factors permanently challenging the livelihoods of millions. We assess whether and to what extent varying intensities of conflict impact economic activity in Palestine which has been subject to substantial violent political conflict for decades. In particular, we analyse the relationship between various intensity levels of political instability measured by conflict-caused fatalities and uncertainty of weekly food prices in the West Bank between 2004 and 2011 using a GARCH model. We consider four food commodities covering vegetables, fruits and animal products. Banana and milk prices are found not to show clustered volatility while onion and pear prices do. The impact of varying conflict intensities on weekly average prices appears to be modest. This might suggest that effects happen on a temporally and geographically more disaggregated scale.
\end{abstract}

Keywords: Food prices, MENA, Middle East, Uncertainty, War.

\section{Introduction}

The long-lasting political conflict between Israel and the Palestinians has been of large importance both for politics and the economies in the Middle East (Shosan and Grootens, 2010). One major effect of this political struggle is the increasing societal and economic separation between Israelis and Palestinians due to a number of security policies implemented by Israel depending on the temporarily changing intensity of the political conflict in order to control potential security threats for the Israeli population
(Dobers et al., 2018). Examples are the West Bank Barrier erected in order to prevent the infiltration of armed Palestinians into Israel or temporary and permanent check points and road blocks which inhibit or prevent the movement of people and goods within the West Bank. These measures heavily affect the Palestinian civilian population in the West Bank and Gaza (Akkaya et al., 2008) which has, in consequence, to deal with a number of factors substantially challenging their individual economic livelihoods which creates despair and sustained destabilization.

\footnotetext{
* Agricultural Economics and Rural Policy Group, Wageningen University, Wageningen, The Netherlands.

** Institute of Business and Economics, Al-Quds University, Abu Deis-Jerusalem, Palestine.

*** Department of Agricultural Economics and Rural Development, Chair of Agricultural Policy, Georg-AugustUniversität, Göttingen, Germany.

Corresponding author: rico.ihle@wur.nl
} 
This research aims at providing evidence on such kind of economic effects of conflict for supporting the development of sustainable strategies for peaceful co-existence. Among the very limited existing data able to measure such effects, food prices are extensively collected by Palestinian authorities due to their importance for the agricultural sector and the food security of the population so that price series are available for a number of years and various commodities. Because food production, trade and marketing are subject to considerably more challenges during phases of increased conflict intensity, we aim at obtaining evidence on the questions whether the levels and volatility of food prices are affected by the waves of violence which have been recurring for decades, whether there was a discernible dividend for relatively more peaceful periods yielding calmer prices and how much the magnitude of this difference was.

We analyse the impact of the intensity of the conflict on the first two moments of a number of food price series - 356 weekly observations between 2004 and 2011 - by estimating a Generalized Autoregressive Conditional Heteroscedasticity $(\mathrm{GARCH})$ model and explicitly accounting for conflict intensity. A unique dataset of disaggregated numbers of conflict-caused fatalities gathered by the Israeli human rights NGO B'Tselem complement the food price data. Based on that data, we construct several variables measuring the intensity of conflict in order to provide comprehensive and robust evidence on the impact of the varying intensity of the conflict on Palestinian food prices. Hence, we present unique evidence on whether and by how much the varying intensity of the political conflict translated into measurable uncertainty in food markets of the West Bank (for Gaza not enough data was available).

The following section presents a concise literature review which is followed by background information on the Palestinian food sector and conceptual considerations on potential relationships between conflict intensity and food price volatility. The fourth section presents details on the chosen modelling approach and the estimated equations. Section five presents the datasets used. The paper closes with presenting the estimation results and discusses conclusions, future research needs and policy implications.

\section{Literature review}

The SIPRI Yearbook (2013) reports an increase of state-based and non-state conflicts since the start of the new millennium. It provides a strong motivation for increased research on the effects of armed conflict. The consequences for the livelihoods of the civilian populations who have to live subject to such conditions are of crucial importance as well as the role armed conflict plays for development and economic prosperity as highlighted by the World Development Report 2011 (World Bank, 2011). Therefore, the analysis of economic consequences of violent political conflict and instabilities has been attracting increasing attention from science in recent years. Blattman and Miguel (2010) provide a comprehensive review of the existing economic literature on this topic.

Impacts of price shocks and volatility on the well-being of the most vulnerable parts of a population depends on many factors (FAO, 2011). The bottom line of this literature is that food prices, and therefore also unexpected shocks to these prices and periods of volatility, affect poverty and inequality through consumption and income channels depending on the income shares devoted to single food commodities (Anderson et al., 2014) ${ }^{1}$.

Only a few analyses concerning the economic effects of the Israeli-Palestinian conflict have been published in the economic literature although international organizations concerned with economic development or food security have produced a wide range of analyses (UN OCHAoPt, 2014; WFP, 2014; World Bank, 2014). Most analyses have focused so far on the effects of the movement restrictions which have been implemented by Israeli authorities due to the conflict, on the Palestinian economy (e.g., Cobham, 2001, Akkaya et al., 2008;

${ }^{1}$ We thank an anonymous reviewer for emphasizing this point. 
World Bank, 2008, 2010) or on estimating the macroeconomic costs of the conflict (Diwan and Shaban, 1999). Very few papers have devoted their focus towards the fatalities of the conflict (Jaeger and Paserman, 2006, 2008).

There have been only a couple of articles published which assess the effects of this conflict for the Palestinian economy. For example, Zussman and Zussman (2006) and Zussman et al. (2008) focus on effects for stock market indices in Israel and Palestine. To the best of our knowledge, are the only publications which deal with food markets and food security are WFP (2009) and Ihle and Rubin (2013). Both focus on the consequences of movement restrictions and trade obstacles on Palestinian food markets. While the former report gives a comprehensive account of the structure of these markets and the perceptions of Palestinian traders towards the conflict, provides the latter an econometric analysis of the effects of the closures of the West Bank Barrier on food prices in Hebron. Rossignoli et al. (2015) analyze livelihoods and resilience in the dairy cattle sector of Gaza.

Especially since the international food price crisis in 2007/2008, a large amount of studies on food price volatility has been published. FAO (2011) or Ulysses (2014) give comprehensive accounts and overviews of recent research. Brümmer et al. (2013) and García-Germán et al. (2013) provide comprehensive literature reviews on the drivers of price volatility and on its effects on consumers and households. For example, Guillen and Franquesa (2015) assess volatility along the Spanish fresh fish supply chain. Capitanio et al. (2014) assess to what extent risk management tools are effective in reducing volatility of farm income in the context of the Common Agricultural Policy. Boere et al. (2015) examine effects of farm gate price volatility on land use again in the context of the Common Agricultural Policy. Brümmer et al. (2013) identify six explicit drivers which are supply, demand, storage, macroeconomic factors, specific policies and the increasing engagement of financial investors in markets of agricultural commodities. Miscellaneous factors such as information shocks, food scares and scandals are grouped into a seventh category. Political in- stabilities and armed conflict are, however, not mentioned although they play a fundamental role in many regions in the Middle East, south Asia and Sub-Saharan Africa.

The contribution of this article therefore consists in providing a micro-level econometric analysis of the role of violent political conflict for price instabilities in food markets which are of immediate relevance for the livelihoods of the civilians living subject to the conflict. This article also adds to the volatility literature in food and agricultural economics by highlighting the role of political instabilities as a further major driver of food price volatility which has only been marginally recognized in the literature so far. Third, we extent the literature by providing one of the rare analyses of effects of the Israeli-Palestinian conflict on the Palestinian economy.

\section{Institutional background}

Ihle and Rubin (2013) point out that the Israeli and Palestinian food sectors are tightly interwoven despite the recurring political confrontations. Kimhi (2011) assesses the role of agriculture in rural well-being in Israel finding a negative association between the importance of agriculture and rural income. The food producing sectors of both economies differ substantially in their specializations due to diverging relative costs of labour and capital. Palestine tends to produce more labour-intensive commodities such as various vegetables of which cucumbers and tomatoes are the most prominent ones. Palestinian and Israeli food produce often differ by their quality, that is, the latter tends often to be of higher prices than the former. In consequence, the Palestinian trade in food commodities with Israel is quite asymmetric in terms of exported and imported commodities. Israel is its most important destination of exports and the by far main source of imports (see also Dobers et al., 2018).

The intensity of this interdependence has been varying in the past decades mainly due to the political conflict. For example, the Gaza strip served as an important growing area for cut flowers and strawberries for the Israeli market up to the Second Intifada which started in September 2000. However, due to the Israeli block- 
ade of Gaza since 2007, barely any of these trade relationships continues to exist. Food trade between the two geographically separated parts of Palestine $^{2}$ has largely ceased. Palestinian foreign trade largely depends on Israeli authorities because Israel is controlling all borders of the West Bank including its eastern border to Jordan and most of the borders of the Gaza Strip.

Agricultural production in the West Bank takes place by both Palestinian as well as Israeli citizens. The latter is operated in Israeli settlements which are spread across this part of Palestine and where about half a million Israelis live. While the northern and the eastern parts of the West Bank around Jenin and Jericho, respectively, have fertile soils and a rather good water availability which makes them very favourable for food production, is the centre and the south very mountainous and more arid including the Judean Desert in the west of the Dead Sea so that extensive husbandry is there largely the only option for agricultural production. Across the entire West Bank the fierce competition for water and land, the complex political structure of the West Bank where Israeli and Palestinian authorities partly share and partly are solely responsible (for more details, see, e.g., UN OCHAoPt, 2008), between the use in the settlements vs. the use by Palestinians is an issue of fierce confrontation and directly impacts the local potential for food production.

The local and regional potentials of food production and food self-sufficiency vary very strongly depending on natural conditions in combination with pronounced disparities in the population distribution across the West Bank. Major population centres in the arid south (PCBS, 2013, p. 35) dictate the necessity of pronounced agricultural trade across the West Bank, which stretches about $130 \mathrm{~km}$ from north to south and $43 \mathrm{~km}$ from east to west, in order to ensure sufficient local food supply. The Gaza strip, in contrast, is with a length of $40 \mathrm{~km}$ and an average width of $9 \mathrm{~km}$ geographically very small and much more homogenous in its con- ditions for food production. This production is, however, substantially challenged by the high number of $1.8 \mathrm{~m}$ inhabitants and continuously high population growth rates ${ }^{3}$ of more than $3 \%$ per year. Since the growth potential of food production falls short of the sustained high population growth rates since decades, Palestine depends on imports for most kinds of food - a large part of which is coming from Israel.

The conditions of food trade within Palestine and with Israel are determined by two factors which are the land relief and the effects of the political conflict. While relief does not play a role in the Gaza strip, do the high and steep mountain ranges with deeply carved-in valleys covering the centre and south of the West Bank only very restrictively allow for the construction of roads and other infrastructure for food trade. Bridges or tunnels which could bring about much more flexibility in this respect do barely exist due to the strong financial limitations and economic challenges the Palestinian Authority faces. Therefore, roads are frequently constructed along the contours of the mountains which implies that distances tend to be longer. Uphill and downhill sections are more frequent as straight road connections via tunnels and bridges are largely missing. In consequence, transportation times and costs will be substantially larger. Since such geological factors are time-invariant and not man-made, they are not of interest here.

The second decisive factor is the political conflict and its manifold consequences and implications for economic activities and the movement of goods and people. Israeli authorities and the military have been installing and implementing a variety of temporary and permanent measures in order to monitor and control the movements of goods and people within Palestine (e.g., UN OCHAoPt, 2008). These led, however, to manifold economic side-effects affecting both Palestinians and Israelis (Ihle and Rubin, 2013). The extent, intensity and duration of the implementation of such measures varies with the intensity of the conflict and the degrees of escalation. This

\footnotetext{
2 Israel is located in-between so that both parts are separated by about $40 \mathrm{~km}$.

3 Note the following relation between the two parts: the West Bank has more than the fifteen fold of the area of the Gaza Strip while it has only one and a half times the population of it.
} 
means that during peaceful phases many of these installations, such as permanent and flying road check points, tend not to be staffed and not or less strictly operated by the Israeli army such as security checks at the commercial terminals of the West Bank Barrier. Consequently, obstacles for the movement of goods and people tend to reduce during peaceful phases and food supply in Palestine becomes cheaper, uncertainty in trade reduces, physical access to food improves, more commodities tend to be transported and trade tends to thrive temporarily.

In contrast, during phases of violent escalations, the presence of the Israeli army will be markedly increased in Palestine, the implementation of measures will be tightened, military convoys might block roads or besiege towns, curfews might be issued. Uncertainty concerning the physical integrity of the individual Palestinian and her material possessions will substantially increase due to the fighting which make take place in or might shift to the individual's immediate neighbourhood. Depending on the degree of escalation, public live and economic activity will be depressed to a smaller or larger extent. Curfews might prevent any economic interactions because civilians are not allowed to leave their houses. Fields and harvest might become damaged or destroyed. Farmers might temporarily be prevented to access their fields or harvest which might result in spoil the produce. Food trade might halt completely, consumers might panic, prices in food deficit (production) areas might explode (collapse) in the short-run. These are only a few examples of plausible and likely economic effects of violent political conflict on uncertainty in food markets.

We, therefore, focus on the specific question of whether the varying intensity of the conflict has significant effects on the instability of food prices in Palestine.

\section{Modelling approach}

We estimate a time series volatility model and explicitly incorporate measurements of conflict intensity into the estimation equations. In particular, we estimate a Generalized Autoregressive Conditional Heteroscedasticity (GARCH) model because this model family has been shown to be the most adequate for modelling volatility of either stock or food prices.

GARCH models are able to quantify not only the development of the mean of a price series, but also of its temporarily evolving clusters of increased variation. They therefore consist of two equations each of which reflecting one aspect. We follow the large literature on food price volatility and estimate an $\operatorname{AR}(m)-\operatorname{GARCH}(p, q)$ for price returns ${ }^{4}$ which can be formalized as:

$r_{t}=c+\sum_{i=1}^{m} \gamma_{i} r_{t-i}+\epsilon_{t}, \epsilon_{t}=\sigma_{t} z_{t}$

and $z_{t}$ is $i i d$ with a specified distribution and

$$
\begin{gathered}
\sigma_{t}^{2}=\operatorname{VAR}\left(r_{t} \mid F_{t-1}\right)=\mu+\sum_{j=1}^{p} \alpha_{j} \epsilon_{t-j}^{2} \\
+\sum_{k=1}^{q} \beta_{k} \sigma_{t-k}^{2}
\end{gathered}
$$

Equation (1) describes the auto-correlative structure of the price return around its time-independent mean $c$, that is, the partial influences of the observations $r_{t}$ of up to $m$ periods back. Equation (2) models the temporarily appearing clusters of the time-varying volatility of the price returns $\sigma_{t}^{2}$ as impacted by market shocks from the $p$ last periods and a linear function of the volatilities $\sigma_{t-k}^{2}$ of the past $q$ periods which are themselves again functions of former market shocks. This is expressed in quantitative terms as the variance of the returns conditional on the given information set until the past period $F_{t-1}$. Since the literature stresses that parsimonious models typically suffice for such empirical analysis and are not outperformed by sophisticated models (Hansen and Lunde, 2005), we follow this approach and focus on an adapted version of an $\mathrm{AR}(m)$-GARCH $(1,1)$ model.

For ensuring that the chosen model indeed adequately models the data of interest, several statistical tests have to be carried out which are the following:

\footnotetext{
4 The series modelled need to be stationary. Because price series tend to have unit roots, they cannot be regarded immediately, but rather their returns are usually modelled.
} 
A) Testing of the stationarity of the price and the return series

B) Testing for ensuring the adequate formulation of the mean equation (1), that is, of the lag length $m$ in order to ensure that the series do not contain any remaining serial dependence

C) Testing for the existence of ARCH effects in the residuals of equation (1)

D) Testing for the adequacy of the GARCHspecification by assessing whether any conditional heteroscedasticity is left

For testing for A) we use a standard Augmented-Dickey-Fuller (ADF) test on the price series and their returns and for $\mathrm{B}$ ), C) and D), respectively, a Ljung-Box test on the squared, the standardized and the squared standardized residuals of the correctly specified mean equation (1).

We follow the literature and estimate a $\operatorname{AR}(m)$ $\operatorname{GARCH}(1,1)$ which we adapt in order to be able to account for the intensity of the political conflict. As measure of the conflict intensity we use the numbers of daily conflict-related fatalities in Palestine which are collected and published by the Israeli human rights NGO B'Tselem. Following the volatility literature, the lag structure of the mean equation (1) is determined for each return series in order to remove any serial correlation. The volatility equations are assumed to be $p=q=1$ for all series so that the volatility model becomes:

$$
\sigma_{t}^{2}=\mu+\alpha_{1} \epsilon_{t-1}^{2}+\beta_{1} \sigma_{t-1}^{2}
$$

This GARCH $(1,1)$ equation is augmented by the following term: $D_{t}\left(\theta+\alpha_{2} \epsilon_{t-1}^{2}+\beta_{2} \sigma_{t-1}^{2}\right)$ where $D_{t}$ denotes a dummy variable measuring the intensity of the conflict.

One very plausible measure of this intensity is the number of weekly fatalities caused by the conflict. This implies the question of what option appears to be the most useful and most meaningful way to incorporate the information contained in this variable into the model. Options might be including it as an integer count variable or as some transformation, e.g., in the form of several categories. A count variable is only limitedly meaningful for measuring conflict intensity because its interpretation would be of the type: if fatalities increase by one unit from one week to the next, volatility changes by the estimated amount. This change would be constant no matter what were fatalities numbers of the first of the two weeks. That is, it is not straightforward to tell whether, for example, an increase in weekly fatality numbers by five, for example, necessarily means that the conflict became more severe because such a statement is only meaningful in relation to a reference period. An increase from zero to five from one week to the next implies certainly an increased conflict intensity because the conflict changed from a rather peaceful state to a state of significant confrontation. However, this interpretation does not hold for a change from, e.g., 200 to 205 fatalities. Based on absolute changes in fatality numbers which such an approach would imply, it is furthermore arbitrary above which threshold of changes in weekly fatalities the conflict intensity is to be labelled as "modest" or "high" etc.. We, therefore, select the observed distribution (Figure 1) of weekly fatality numbers during this period as reference and define the following three categories which characterize three different intensity states of the political conflict in order to be able to explicitly quantify differences in the intensity of conflict (Table 1).

Therefore, we estimate the following three volatility equation specifications:

$$
\begin{aligned}
& \sigma_{t}^{2}=\mu+\alpha_{1} \epsilon_{t-1}^{2}+\beta_{1} \sigma_{t-1}^{2} \\
& +D_{t}^{a n y}\left(\mu_{c}+\alpha_{c} \epsilon_{t-1}^{2}+\beta_{c} \sigma_{t-1}^{2}\right),
\end{aligned}
$$

$\sigma_{t}^{2}=\mu+\alpha_{1} \epsilon_{t-1}^{2}+\beta_{1} \sigma_{t-1}^{2}$

$+D_{t}^{\text {med }}\left(\mu_{c}+\alpha_{c} \epsilon_{t-1}^{2}+\beta_{c} \sigma_{t-1}^{2}\right)$,

$\sigma_{t}^{2}=\mu+\alpha_{1} \epsilon_{t-1}^{2}+\beta_{1} \sigma_{t-1}^{2}$

$+D_{t}^{90 Q}\left(\mu_{c}+\alpha_{c} \epsilon_{t-1}^{2}+\beta_{c} \sigma_{t-1}^{2}\right)$.

This means that we assess whether and to what extent the three above-defined escalations states change the mean volatility in week $t$ to $\mu+\mu_{c}$ and/ or its dynamic structure in terms of its response to the shock $\varepsilon_{t-1}$ of the previous week and to the volatility $\sigma_{t-1}^{2}$ of the previous week. The last column of Table 1 indicates that the observations during which the three states exist differ strongly: while only $22 \%$ of the 
Table 1 - Dummy variable definition.

\begin{tabular}{|l|l|l|l|l|c|}
\hline \multicolumn{1}{|c|}{ State } & \multicolumn{1}{|c|}{ Dummy variable } & \multicolumn{2}{c|}{ Interpretation } & Mean \\
\cline { 2 - 5 } & Name & \multicolumn{1}{|c|}{ Definition } & \multicolumn{1}{c|}{$D_{t_{t}}^{*}=0$} & \multicolumn{1}{c|}{$D_{t}^{*}=1$} \\
\hline Some conflict & $D_{t}^{\text {any }}$ & $\begin{array}{l}D_{t}^{\text {any }}=1 \text { if there were any fatalities } \\
\text { in week } t\end{array}$ & Peaceful & $\begin{array}{l}\text { Any conflict of some } \\
\text { unspecified intensity }\end{array}$ & 0.78 \\
\hline $\begin{array}{l}\text { Intensive } \\
\text { conflict }\end{array}$ & $D_{t}^{\text {med }}$ & $\begin{array}{l}D_{t}^{\text {med }}=1 \text { if there were at least as } \\
\text { many fatalities in week } t \text { as the } \\
\text { median of the fatality distribution }\end{array}$ & $\begin{array}{l}\text { Not } \\
\text { markedly } \\
\text { increased }\end{array}$ & $\begin{array}{l}\text { Markedly increased } \\
\text { intensity }\end{array}$ & 0.59 \\
\hline $\begin{array}{l}\text { Extremely high } \\
\text { conflict }\end{array}$ & $D_{t}^{900}$ & $\begin{array}{l}D_{t}^{900}=1 \text { if there were at least as } \\
\text { many fatalities in week } t \text { as the } 90 \% \\
\text { quantile of the fatality distribution }\end{array}$ & $\begin{array}{l}\text { Less than } \\
\text { extreme }\end{array}$ & $\begin{array}{l}\text { Extremely violent } \\
\text { week }\end{array}$ & 0.11 \\
\hline
\end{tabular}

Source: Authors.

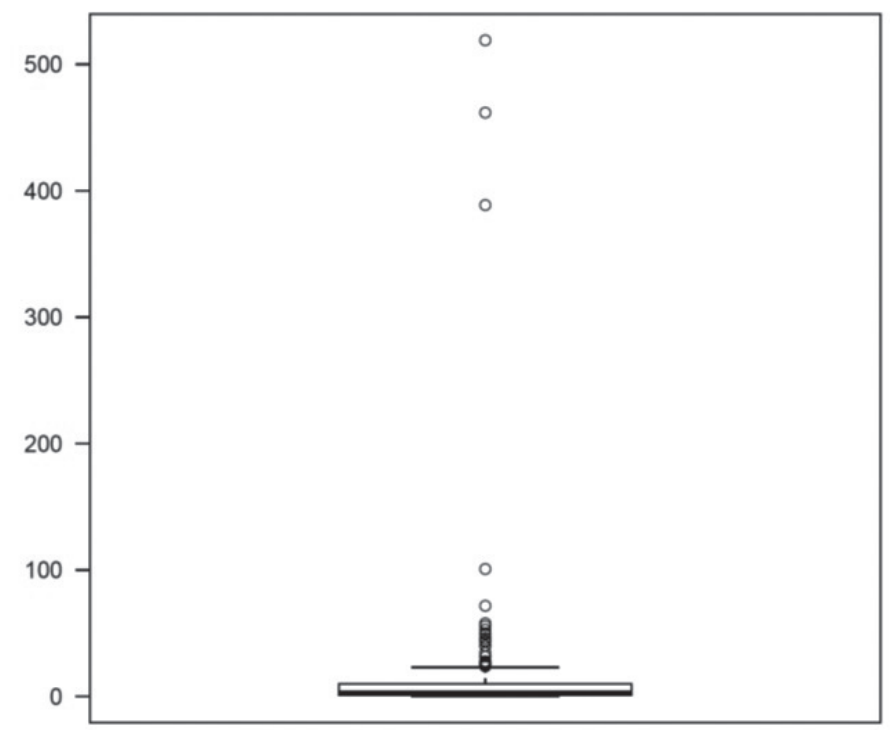

Figure 1 - Boxplot of weekly conflictcaused fatalities in Palestine.

Source: Authors. weeks between 2004 and 2011 were peaceful in the sense that no Palestinian fatalities occurred, in $59 \%$ of the time the conflict was intense and $11 \%$ of observations were extremely violent.

\section{Data}

We regard eight price series of four commodities of which both Palestinian and Israeli varieties or brands are sold in Palestine. Food price data of the Palestinian Central Bureau of Statistics provides information both of brands or varieties on differing sources of several commodities. Of those, we regard the following four products in order to cover at least one vegetable, fruit and animal food commodity: bananas, milk, onions and pears. Table 2 outlines the differenc- es between the Palestinian- and Israeli-produced versions of these commodities sold in Palestine.

Table 3 shows a selected set of descriptive statistics of the eight regarded price series. Milk as animal product and pears as a more luxury fruit in the Palestinian diet have the highest prices on average among the four commodities. For both, Israeli prices are on average close to $6 \mathrm{NIS} / \mathrm{kg}$ while price ranges are among the lowest differing for milk only by about 2-3 NIS. Onions and bananas have lowest average prices of about 2.4 and 3.4 NIS, respectively. The most frequently observed prices range for most commodities lies in the interval between 2 and 4.5 NIS.

Median prices are below mean prices for bananas and onions, at the level of mean prices for milk and slightly exceed mean pear prices. 
Table 2 - Description and origins of regarded commodities.

\begin{tabular}{|l|l|c|}
\hline Variable name & PCBS Description & $\begin{array}{c}\text { Number of missing } \\
\text { observations }\end{array}$ \\
\hline Palestinian-produced bananas & Large-sized bananas & 4 \\
\hline Israeli-produced bananas & Medium-sized bananas & 0 \\
\hline Palestinian-produced milk & Pasteurized milk 3\% fat & 10 \\
\hline Israeli-produced milk & Pasteurized milk 3\% fat of brand Tnuva & 1 \\
\hline Palestinian-produced onions & Dry Baladi onions & 2 \\
\hline Israeli-produced onions & Dry onions & 4 \\
\hline Palestinian-produced pears & Common pears & 0 \\
\hline Israeli-produced pears & Yellow pears & 0 \\
\hline
\end{tabular}

Source: Authors based on PCBS (2012).

Notes: ${ }^{a}$ The few missing observations are imputed based on a structural time series model according to the state-space approach of Harvey (1989).

The relative variability in terms of the $\mathrm{CV}$ is on a similar level of about 0.2 for five of the eight commodities. Thus, the variabilities of Israeliand Palestinian-produced commodities almost equal each other except for pears. Milk products show about half of this variability which is plausible due to the strong governmental regulation in Israeli milk markets (Bar Nahum, 2012; Bar Nahum et al., 2013). The very similar variability of Palestinian milk suggests either that the Palestinian Authority is following a similar intervention scheme or that Palestinian milk prices closely follow the Israeli ones.
Figure 2 plots the weekly series of these eight commodity prices obtained from PCBS (2012). They range from the first week of January 2004 until end of May 2011 and have 356 observations each. These prices are average retail prices of the respective commodity in all West Bank regions ${ }^{5}$. They suggest a markedly differing price behaviour for the four commodities. Prices of onions of Palestinian and Israeli origin are very close to each other amounting to an average difference of $-0.07 \mathrm{NIS} / \mathrm{kg}$. While prices of Israeli-produced bananas are on average 0.43 NIS higher than of Palestinian-produced ones, much larger average

Table 3 - Descriptive statistics of the commodity price series in NIS $/ \mathrm{kg}$.

\begin{tabular}{|l|c|c|c|c|c|c|c|c|}
\hline & $\begin{array}{c}\text { Bananas } \\
\text { Palestine }\end{array}$ & $\begin{array}{c}\text { Bananas } \\
\text { Israel }\end{array}$ & $\begin{array}{c}\text { Milk } \\
\text { Palestine }\end{array}$ & $\begin{array}{c}\text { Milk } \\
\text { Israel }\end{array}$ & $\begin{array}{c}\text { Onions } \\
\text { Palestine }\end{array}$ & $\begin{array}{c}\text { Onions } \\
\text { Israel }\end{array}$ & $\begin{array}{c}\text { Pears } \\
\text { Palestine }\end{array}$ & $\begin{array}{c}\text { Pears } \\
\text { Israel }\end{array}$ \\
\hline Min. & 1.25 & 2.23 & 3.83 & 5.00 & 1.25 & 1.50 & 1.75 & 4.12 \\
\hline Max. & 5.23 & 6.28 & 7.00 & 7.13 & 4.79 & 5.67 & 9.00 & 8.53 \\
\hline Range & 3.98 & 4.05 & 3.17 & 2.13 & 3.54 & 4.17 & 7.25 & 4.40 \\
\hline Mean & 3.21 & 3.61 & 5.14 & 5.89 & 2.52 & 2.44 & 4.88 & 6.32 \\
\hline Mode & 4.00 & 3.78 & 5.00 & 5.50 & 2.50 & 2.00 & 5.50 & 7.00 \\
\hline Median & 3.02 & 3.50 & 5.13 & 5.76 & 2.42 & 2.28 & 4.95 & 6.35 \\
\hline Std & 0.70 & 0.74 & 0.45 & 0.53 & 0.61 & 0.61 & 1.02 & 0.84 \\
\hline CV & 0.22 & 0.21 & 0.09 & 0.09 & 0.24 & 0.25 & 0.21 & 0.13 \\
\hline
\end{tabular}

Source: Authors based on PCBS (2012).

\footnotetext{
${ }^{5}$ Gaza had to be excluded because the series contained many missing observations.
} 
Figure 2 - Time series of regarded commodities in NIS $/ \mathrm{kg}$.

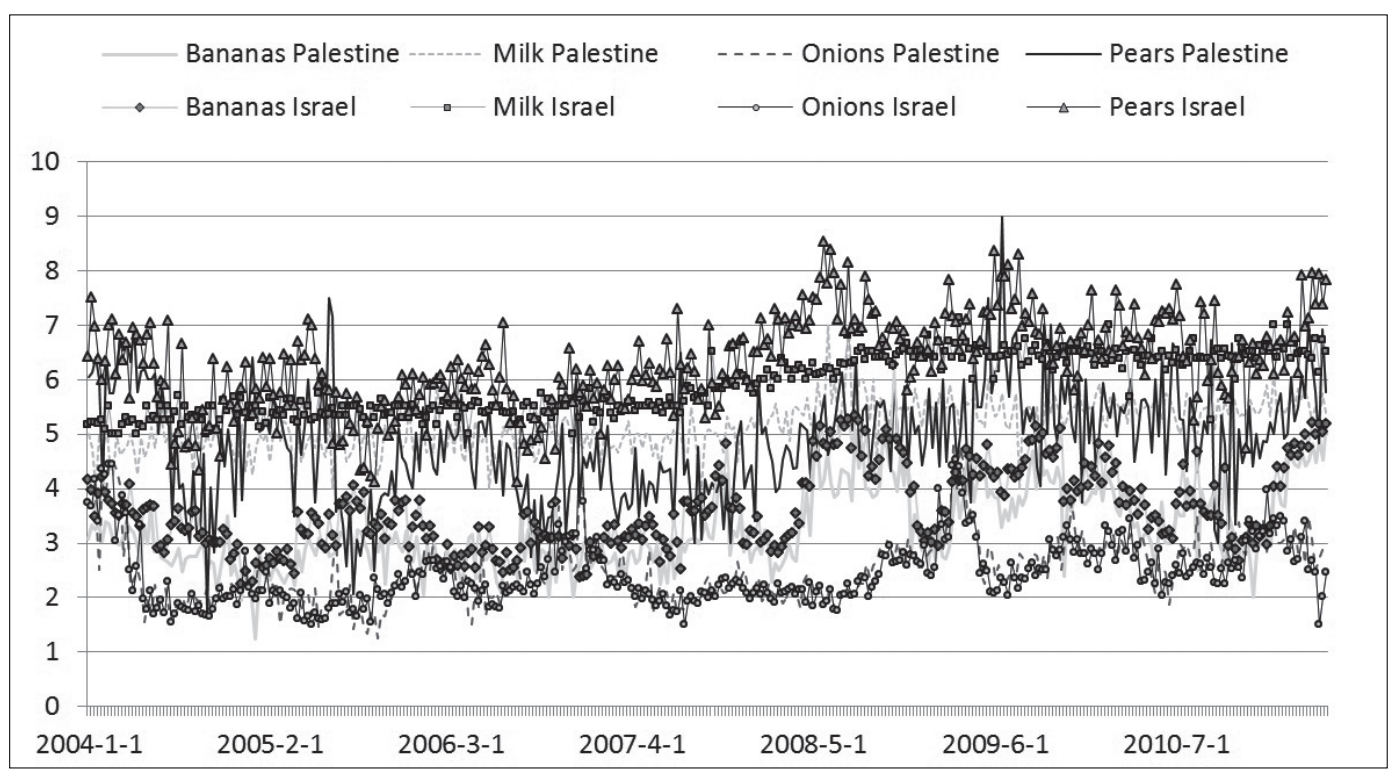

Source: Authors based on PCBS (2012).

Notes: NIS denotes the Israeli currency New Israeli Shekel which is besides the Jordanian Dinar the most frequently used currency in Palestine.

differentials of 0.88 and 1.5 NIS exist for milk and pears, respectively.

Figure 3 plots the kernel density estimates of the distributions of the weekly returns of the commodity series calculated as

$r_{t}=\ln \left(p_{t} / p_{t-1}\right)$

Hence, the returns are the log transformation of the percentage short-run price changes which take place from period to period, that is, from week to week. They signal the magnitude and direction of the relative price changes so that $r_{t}=0$ means that prices in subsequent periods did not change.

Figure 3 illustrates that the distributions of the prices of Palestinian-produced commodities have much heavier tails for all commodities except onions. This points to the fact that prices of Palestinian produce are markedly more volatile, that is, they incorporate much more uncertainty because extreme values at the edges of the distributions occur with a higher probability than in case of the Israeli-produced commodity versions. This suggests that prices of Palestinian produce react more sensitively and strongly to shocks which might either be caused by the Israeli-Palestinian conflict or by other demand or supply factors. The above-discussed stability of Israeli milk prices becomes particularly obvious in this figure.

Figure 4 plots the squares of the price returns in order to give a visual impression of the existence of volatility clustering in these food price series. It supports the above observation that prices of Palestinian-produced food tend to be much more volatile. Notable clusters of raised uncertainty in several of the food prices occur until September 2005, in the second half of 2006, the middle of 2007, in entire 2009 and at the end of 2010. Mostly, onions and pears show temporarily increased volatility while for the returns of banana prices only a few high spikes are discernible signalling strong inter-period prices changes.

In order to be able to measure the intensity of the conflict, we obtained data on daily numbers of conflict-caused Palestinian fatalities from the Israeli human rights NGO B'Tselem (2013) which is based in Jerusalem and collects 


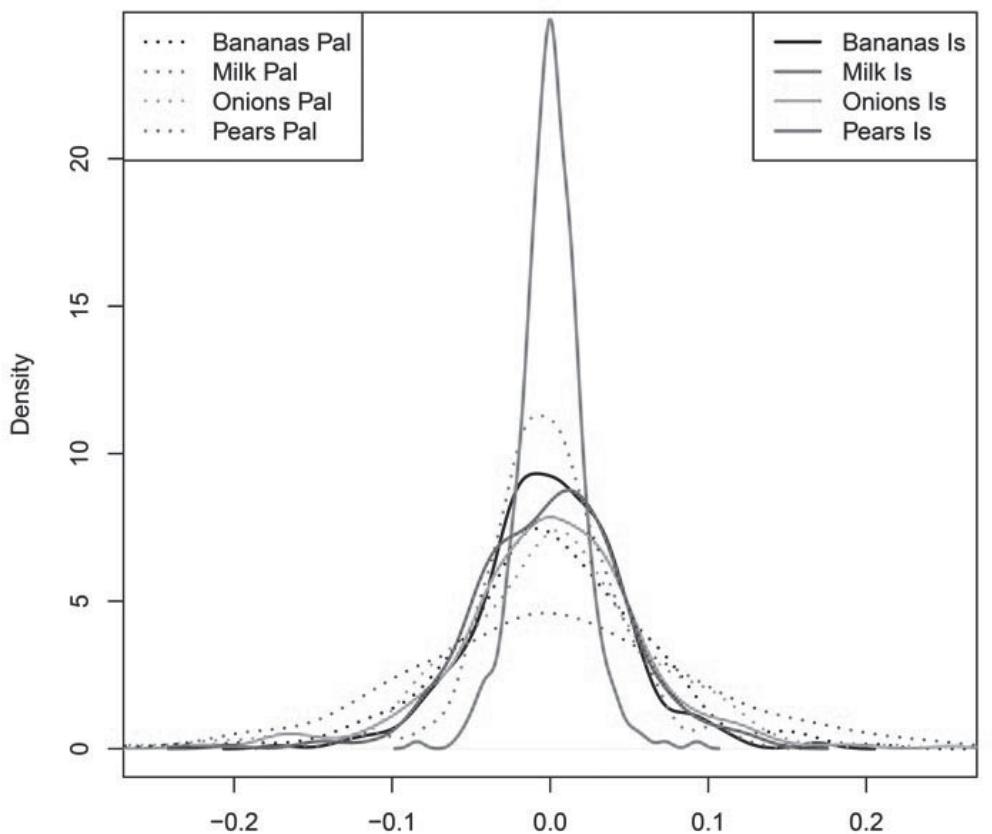

Figure 3 - Distributions of commodity returns.

Source: Authors. and publishes comprehensive data on various dimensions of the Israeli-Palestinian conflict. Table 4 presents several descriptive statistics of the fatality numbers aggregated at weekly level in order to match the frequency of the available price data whose distribution is illustrated by Figure 1 above. Weekly Palestinian fatalities range from zero to 519 during the period be- tween January 2004 and end of May 2011. The largest observations of weekly fatalities happened at the end of 2008 and in January 2009 when the Israeli Army carried out the Operation Cast Lead in the Gaza Strip as Figure 5 shows.

The strong discrepancy between the median and mean of weekly fatalities of three and 11, respectively, suggests that the distribution of

Figure 4 - Squared returns of commodities series.

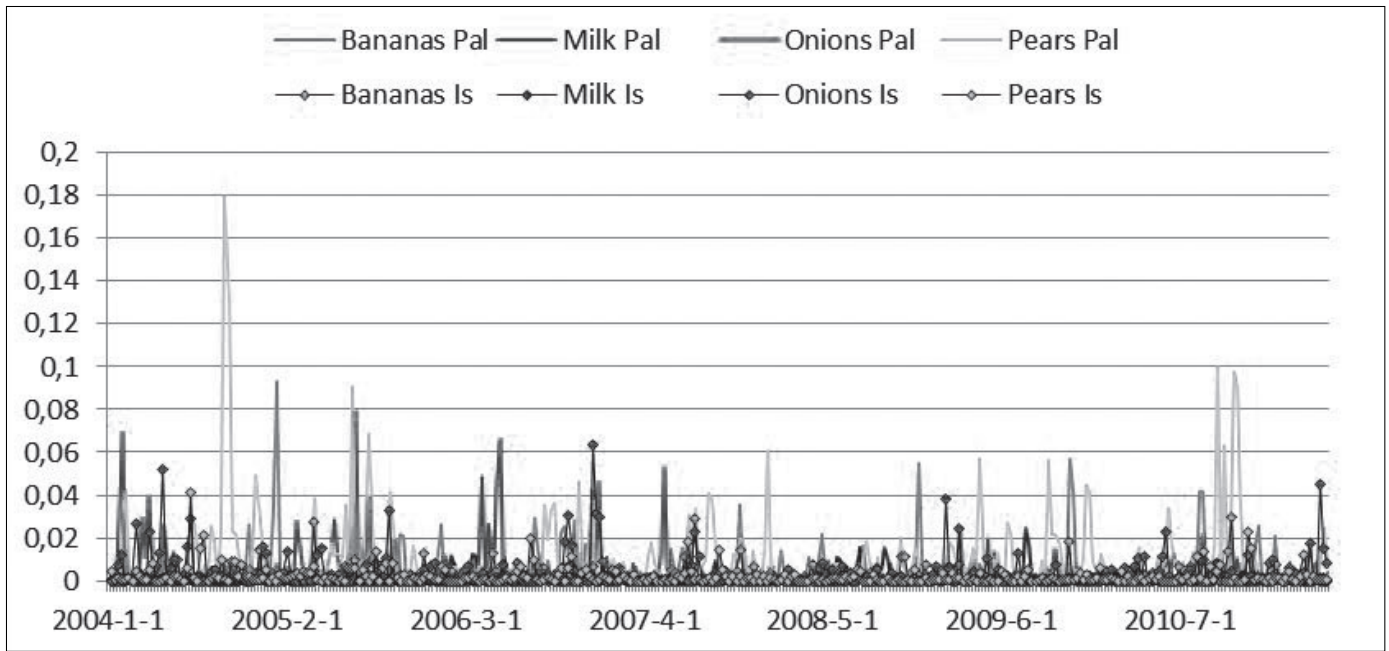

Source: Authors. 
Table 4 - Descriptive statistics of the Palestinian fatalities per week 2004-2011.

\begin{tabular}{|l|c|c|c|c|c|c|}
\hline & Minimum & $1^{\text {st }}$ quartile & Median & Mean & $3^{\text {rd }}$ quartile & Maximum \\
\hline Fatalities/week & 0 & 1 & 3 & 11.3 & 10 & 519 \\
\hline
\end{tabular}

Source: Authors based on B'Tselem (2013).

the weekly fatalities is strongly right-skewed (Figure 1) due to a few observations beyond 100. For a quarter of the 356 observations at least 10 fatalities occurred. The temporal development in Figure 5 shows several periods of markedly increased fatality numbers which can certainly be thought of as waves of increased conflict which took place up to the first months of 2005 marking the end of the Second Intifada, during the second half of 2006, the first half of 2008 and the Operation Cast Lead.

Figure 6 illustrates the temporal locations of $D_{t}^{*}=1$ of the three dummy variables defined in Table 1 above. Especially during 2009 and 2010 less weeks with fatalities occurred. The observations of $D_{t}^{90 Q}=1$ mark five periods of extremely high conflict intensity two of which had a very short duration but led to high numbers of victims.

Figure 5 - Temporal development of weekly conflict-caused Palestinian fatality numbers.

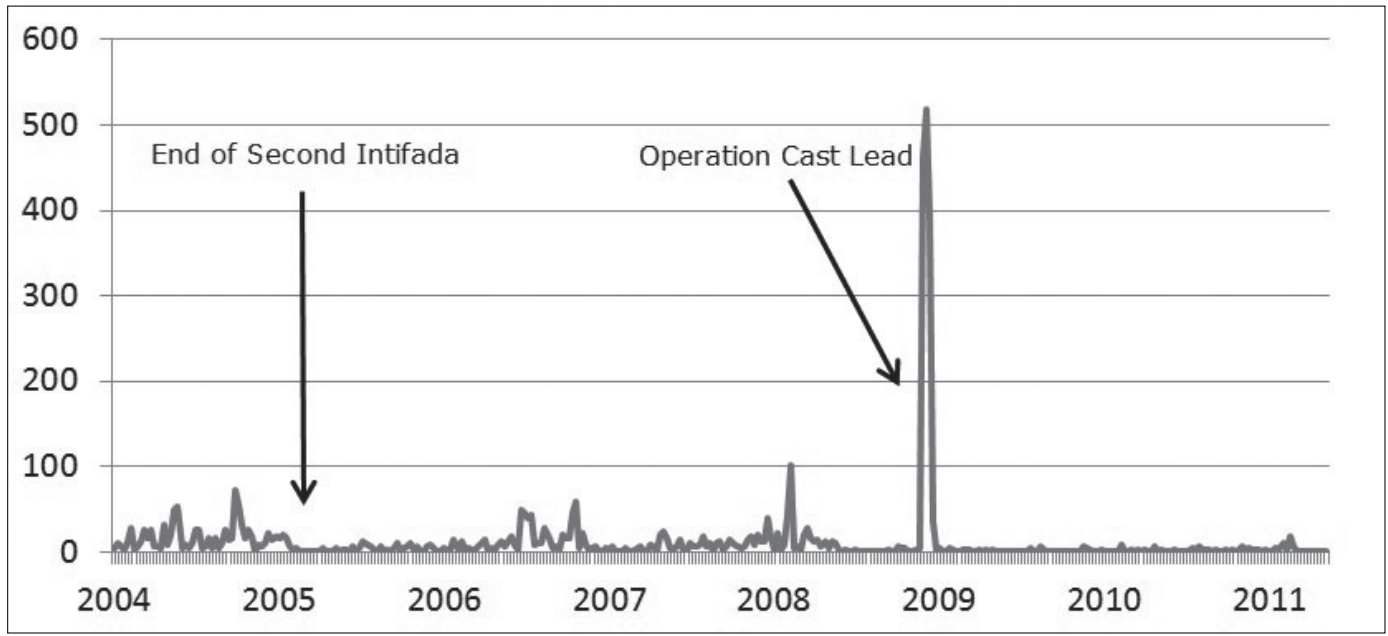

Source: Authors based on B'Tselem (2013).

Figure 6 - Realizations of the conflict intensity dummies.

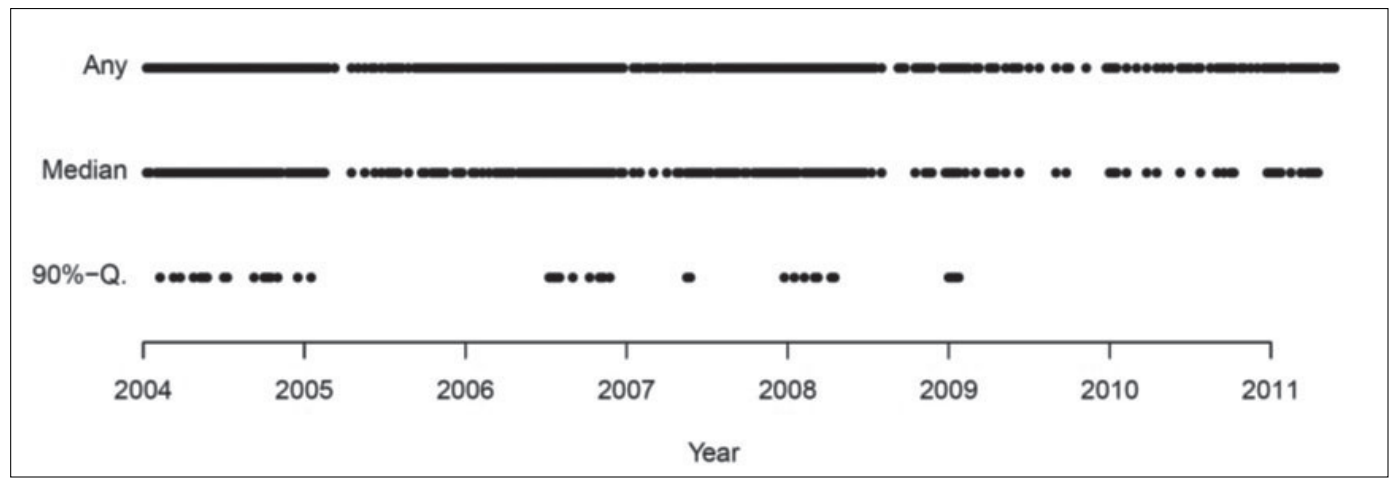

Source: Authors. 


\section{Results}

Table 5 shows the results of the above-mentioned specification tests A) to D). The ADF tests suggest that banana, milk and Israel pear prices might have a unit root at the $5 \%$ level of significance. Their test statistics are close or only slightly larger than the critical value of -3.41 suggesting that the null hypothesis of a unit root cannot be rejected. The statistics of the remaining three series are somewhat smaller than the critical value but still close. However, the test statistics of the returns of all series signal strong evidence that the null hypothesis of a unit root can be rejected so that we use these transformations for the analysis.

The optimal lag lengths $m$ of the autoregressive structure of the mean equation (2) have been determined based on repeated testing so that they represent the minimum lag length which is necessary in order to remove any serial correlation and conditional heteroscedasticity in the residuals of the modelling system (1) and (2). Average onion returns appear to have the shorted autoregressive structure of only 1 to 2 weeks while milk price returns but also those of Palestinian pears are significantly impacted by their own past price changes of the last one and a half months. This appears plausible for milk due to the above-mentioned marketing framework. The ARCH tests suggest that bananas and milk returns do not show any clustered volatility while this phenomenon seems to be very strong for onions and pears. Therefore, the latter to commodity returns have to be modelled using a volatility model in order to avoid misspecification. We also estimate such models for the banana and milk price returns although the test results suggest that there might be barely significant relations be found.

Table 6 to Table 8 show the estimation results of the volatility equations (M1) to (M3) of all three conflict intensity dummies for all eight commodities. Table 6 focuses on the effects of any fatalities in any week on volatility. The last two lines with the results of the above-described tests B) and D) indicate that almost all models are adequate accounts of reality. The only exception are Palestinian pears for which some remaining conditional heteroscedasticity is signalled to be left in the residuals of the final model. The first three lines of the table refer to $D_{t}^{a n y}=0$, that is, peaceful weeks without any fatalities. For Israeli-produced bananas and Palestinian-produced onions and pears, the constant $\mu$ is significantly positive. Shocks to the returns of the previous period significantly affect current volatility in six cases $\left(\alpha_{1}\right)$. While the magnitudes of the effects is closely below zero for milk and Israeli pears, it is five times stronger in magnitude and positive for Palestinian-produced bananas, onions and pears. This indicates that weekly prices of milk, Israeli-produced bananas and pears are in general much less impacted by shocks in the short-term. Volatility clustering $\left(\beta_{1}\right)$ is found to be strong for Israeli-produced milk and pears and Palestinian onions.

Table 5 - Results of model specification tests.

\begin{tabular}{|l|c|c|c|c|c|c|c|c|}
\hline & $\begin{array}{c}\text { Bananas } \\
\text { Pal }\end{array}$ & $\begin{array}{c}\text { Bananas } \\
\text { Israel }\end{array}$ & $\begin{array}{c}\text { Milk } \\
\text { Pal }\end{array}$ & $\begin{array}{c}\text { Milk } \\
\text { Israel }\end{array}$ & $\begin{array}{c}\text { Onions } \\
\text { Pal }\end{array}$ & $\begin{array}{c}\text { Onions } \\
\text { Israel }\end{array}$ & $\begin{array}{c}\text { Pears } \\
\text { Pal }\end{array}$ & $\begin{array}{c}\text { Pears } \\
\text { Israel }\end{array}$ \\
\hline ADF statistic of prices & -3.42 & -3.34 & -3.55 & -2.45 & -4.48 & -5.91 & -5.17 & -3.80 \\
\hline ADF statistic of returns & -17.78 & -18.47 & -13.95 & -13.07 & -16.30 & -15.98 & -12.57 & -17.78 \\
\hline Optimal AR-lag $m$ & 3 & 2 & 6 & 5 & 1 & 2 & 5 & 2 \\
\hline$p$-val ARCH test $(F)$ & 0.60 & 0.48 & 0.58 & 0.96 & $<0.01$ & $<0.01$ & $<0.01$ & $<0.01$ \\
\hline$p$-val ARCH test $(L M)$ & 0.60 & 0.47 & 0.57 & 0.96 & $<0.01$ & $<0.01$ & $<0.01$ & $<0.01$ \\
\hline
\end{tabular}

Source: Authors.

Notes: $(F)$ and (LM), respectively, denote the F-test and the Lagrange multiplier version of the ARCH test. The ARCH (unit root) tests have the null hypothesis is that there are no ARCH effects (that the series have a unit root). The critical value of the ADF tests is -3.41, the optimal lag lengths have been selected according to the Hannan-Quinn criterion. 
Table 6 - Results of model M1.

\begin{tabular}{|l|c|c|c|c|c|c|c|c|}
\hline & $\begin{array}{c}\text { Bananas } \\
\text { Pal }\end{array}$ & $\begin{array}{c}\text { Bananas } \\
\text { Israel }\end{array}$ & $\begin{array}{c}\text { Milk } \\
\text { Pal }\end{array}$ & $\begin{array}{c}\text { Milk } \\
\text { Israel }\end{array}$ & $\begin{array}{c}\text { Onions } \\
\text { Pal }\end{array}$ & $\begin{array}{c}\text { Onions } \\
\text { Israel }\end{array}$ & $\begin{array}{c}\text { Pears } \\
\text { Pal }\end{array}$ & $\begin{array}{c}\text { Pears } \\
\text { Israel }\end{array}$ \\
\hline$\mu$ & 0.001 & $0.004^{* *}$ & $<0.001$ & $<0.001$ & $<0.001^{* *}$ & 0.001 & $0.005^{* *}$ & $<0.001$ \\
\hline$\alpha_{1}$ & $0.142^{* *}$ & 0.003 & $-0.061^{* *}$ & $-0.040^{* *}$ & $0.195^{* *}$ & 0.220 & $0.639^{* *}$ & $-0.089^{*}$ \\
\hline$\beta_{1}$ & 0.235 & -0.311 & 0.638 & $0.909^{*}$ & $0.737^{* *}$ & 0.241 & $-0.246^{*}$ & $1.161^{* *}$ \\
\hline$\mu_{c}$ & 0.001 & -0.002 & $<0.001$ & $<0.001^{* *}$ & $<0.001^{*}$ & -0.001 & $-0.005^{* *}$ & $<0.001$ \\
\hline$\alpha_{c}$ & -0.090 & 0.166 & 0.088 & 0.013 & 0.018 & -0.107 & $-0.465^{*}$ & $0.150^{* *}$ \\
\hline$\beta_{c}$ & -0.759 & 0.677 & -0.104 & -0.865 & -0.030 & 0.603 & $0.920^{* *}$ & $-0.303^{*}$ \\
\hline $\mathrm{B})$ & 0.12 & 0.26 & 0.06 & 0.54 & 0.11 & 0.09 & 0.07 & 0.11 \\
\hline $\mathrm{D})$ & 0.16 & 0.41 & 0.20 & 0.93 & 0.93 & 0.06 & $<0.01^{* *}$ & 0.10 \\
\hline
\end{tabular}

Source: Authors.

Notes: * and $* *$ denote significance at the $5 \%$ and $1 \%$ level, respectively. $<0.001$ means that the coefficient is larger than 0 but smaller than 0.001. B) and D) denote the tests mentioned above, these lines contain the p-values of the test results.

During periods of conflict of unspecified intensity (lines $\mu_{c}$ to $\beta_{c}$ ) average returns of weekly food prices increase significantly but at small magnitude for Israeli milk and Palestinian onions and decrease for Palestinian pears. Changes in the dynamic structure, which are substantial in magnitude, are only found for pears. The estimate of $\alpha_{c}$ and $\beta_{c}$ are about thrice as large for Palestinian pears and of opposite sign for than for Israeli pears.

Table 7 suggests that markedly increased conflict intensity as measured by $D_{t}^{\text {med }}$ barely impacts the weekly return series. Only for milk seems to be a slight effect. Again all model adequacy tests are fine except for Palestinian pears.

Table 8 contrasts the volatility during extremely violent phases as defined in Table 1 to phases without such extreme escalations. Effects on weekly returns appear to be modest in number and magnitude since only the constants are significantly changed although magnitudes turn out to be small.

Figure 7 summarizes the significant effects of Table 6 to Table 8 and the directions of the

Table 7 - Results of model M2.

\begin{tabular}{|l|c|c|c|c|c|c|c|c|}
\hline & $\begin{array}{c}\text { Bananas } \\
\text { Pal }\end{array}$ & $\begin{array}{c}\text { Bananas } \\
\text { Israel }\end{array}$ & $\begin{array}{c}\text { Milk } \\
\text { Pal }\end{array}$ & $\begin{array}{c}\text { Milk } \\
\text { Israel }\end{array}$ & $\begin{array}{c}\text { Onions } \\
\text { Pal }\end{array}$ & $\begin{array}{c}\text { Onions } \\
\text { Israel }\end{array}$ & $\begin{array}{c}\text { Pears } \\
\text { Pal }\end{array}$ & $\begin{array}{c}\text { Pears } \\
\text { Israel }\end{array}$ \\
\hline$\mu$ & 0.002 & 0.002 & $<0.001$ & $<0.001$ & $<0.001$ & 0.001 & 0.002 & $<0.001$ \\
\hline$\alpha_{1}$ & $0.143^{*}$ & 0.007 & $-0.072^{* *}$ & 0.005 & 0.073 & 0.072 & 0.147 & 0.008 \\
\hline$\beta_{1}$ & 0.096 & 0.339 & 0.652 & $1.049 * *$ & $0.768^{* *}$ & $0.686 * *$ & $0.507 *$ & $0.956^{* *}$ \\
\hline$\mu_{c}$ & $<0.001$ & -0.001 & $<0.001$ & $<0.001$ & $<0.001$ & $<0.001$ & -0.001 & $<0.001$ \\
\hline$\alpha_{c}$ & -0.039 & 0.084 & $0.162^{*}$ & $-0.064 * *$ & 0.229 & 0.066 & 0.125 & 0.125 \\
\hline$\beta_{c}$ & -0.533 & 0.424 & -0.094 & -0.203 & -0.117 & 0.140 & 0.127 & -0.217 \\
\hline B) & 0.22 & 0.17 & 0.08 & 0.42 & 0.08 & 0.12 & 0.18 & 0.09 \\
\hline D) & 0.55 & 0.57 & 0.12 & 0.97 & 0.88 & 0.48 & $0.01 * *$ & 0.07 \\
\hline
\end{tabular}

Source: Authors.

Notes: * and ** denote significance at the 5\% and $1 \%$ level, respectively. $<0.001$ means that the coefficient is larger than 0 but smaller than 0.001. B) and D) denote the tests mentioned above, these lines contain the p-values of the test results. 
Table 8 - Results of model M3.

\begin{tabular}{|l|c|c|c|c|c|c|c|c|}
\hline & $\begin{array}{c}\text { Bananas } \\
\text { Pal }\end{array}$ & $\begin{array}{c}\text { Bananas } \\
\text { Israel }\end{array}$ & $\begin{array}{c}\text { Milk } \\
\text { Pal }\end{array}$ & $\begin{array}{c}\text { Milk } \\
\text { Israel }\end{array}$ & $\begin{array}{c}\text { Onions } \\
\text { Pal }\end{array}$ & $\begin{array}{c}\text { Onions } \\
\text { Israel }\end{array}$ & $\begin{array}{c}\text { Pears } \\
\text { Pal }\end{array}$ & $\begin{array}{c}\text { Pears } \\
\text { Israel }\end{array}$ \\
\hline$\mu$ & $0.001^{* *}$ & $0.002^{* *}$ & $<0.001^{*}$ & $<0.001$ & $0.001^{* *}$ & $<0.001^{*}$ & $0.001^{* *}$ & $0.001^{* *}$ \\
\hline$\alpha_{1}$ & $-0.042^{*}$ & 0.095 & $-0.058^{* *}$ & -0.023 & $0.228^{* *}$ & $0.120^{* *}$ & $0.273^{* *}$ & 0.035 \\
\hline$\beta_{1}$ & $0.329^{* *}$ & 0.175 & $0.659^{* *}$ & 0.288 & $0.662^{* *}$ & $0.713^{* *}$ & $0.493^{* *}$ & $0.411^{* *}$ \\
\hline$\mu_{c}$ & $-0.002^{* *}$ & -0.005 & $<0.001$ & $<0.001$ & $-0.001^{*}$ & -0.001 & $-0.002^{* *}$ & $-0.001^{*}$ \\
\hline$\alpha_{c}$ & $0.345^{* *}$ & -0.115 & -0.050 & 0.039 & -0.010 & 0.478 & 0.447 & 0.434 \\
\hline$\beta_{c}$ & $1.146^{*}$ & 1.985 & -0.782 & 1.065 & 0.221 & 0.211 & 0.076 & 0.723 \\
\hline $\mathrm{B})$ & 0.08 & 0.23 & 0.12 & 0.26 & 0.08 & 0.12 & 0.11 & 0.16 \\
\hline $\mathrm{D})$ & 0.13 & 0.63 & 0.08 & 0.97 & 0.94 & 0.65 & $<0.01 * *$ & $0.01 *$ \\
\hline
\end{tabular}

Source: Authors.

Notes: * and ** denote significance at the $5 \%$ and $1 \%$ level, respectively. $<0.001$ means that the coefficient is larger than 0 but smaller than $0.001 . B$ ) and D) denote the tests mentioned above, these lines contain the p-values of the test results.

partial influences. Positive and negative effects of the dummy interactions (below the bold line) are almost equally frequent. The variable $D_{t}^{\text {any }}$ has most diverse influences on the changes in weekly volatility magnitude and dynamics.

\section{Summary and conclusions}

We address the question of whether and to what extent varying degrees of intensity of political conflict affect the volatility of food prices, that is, whether and to what extent they create uncertainty in markets for basic consumption goods. We therefore contribute to the developing literature which assesses the economic effects of political conflict (Blattman and Miguel, 2010).

We study this question in the context of the Israeli-Palestinian conflict because it has a long and well-documented history so that data both on food prices and on the development of the political struggle is available for longer continuous periods. Because Palestinian civilians are severely affected by the conflict and its consequences, we focus on the effects for food commodities marketed in Palestine. We focus on four commodities: bananas, milk, onions and pears in order to cover vegetables, fruits and

Figure 7 - Summary of the significance and the directions of the interactions.
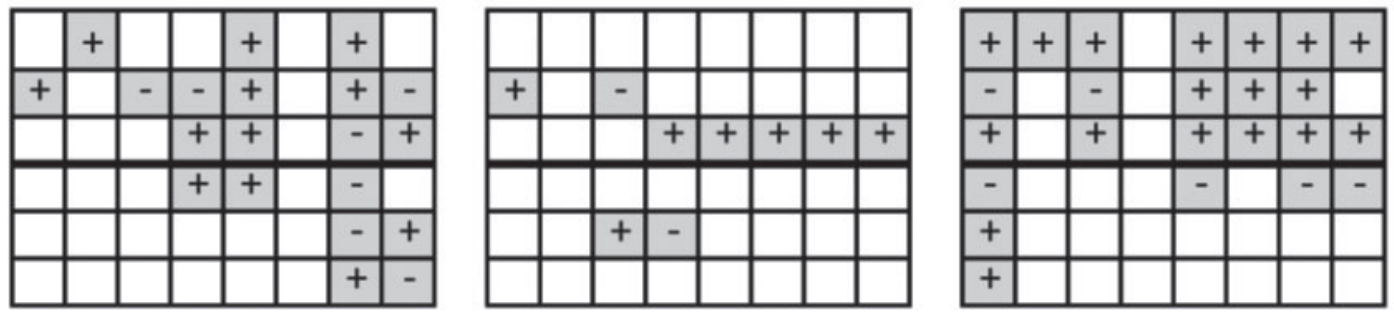

Source: Authors.

Notes: The squares refer from left to right to the results contained in Table 6 to Table 8. The structure of each square corresponds to Table 6 above: the eight columns correspond to the commodities mentioned (same order) and the six lines denote the six coefficients of the volatility equations. Grey cells denote significance at the 5\% level and + (-) denotes a positive (negative) impact on the contemporaneous volatility of the respective commodity return. 
animal products as different types of food. All these commodities are marketed in Palestine and produced in Israel as well as in Palestine. This enables us to identify effects which potentially might differ by the source of the produce due to different trade structures and conflict-related trade obstacles encountered. We propose three dummy variables measuring different escalation stages of the conflict and assess their effects on weekly food prices in the West Bank for the period between 2004 and 2011. Daily numbers of conflict-caused Palestinian fatalities which are aggregated to a weekly level serve as proxy for quantifying the intensity of the instabilities.

We find that returns of weekly banana and milk prices do not show any clustering volatility. The variance of these returns is not time-varying which can be seen as a positive market characteristic for consumers because it means that prices of these two commodities are more or less stable. This result is in line with the shape of the distributions of the two milk prices which are narrow and have short and slim tails. Onions and pears prices, in contrast, show strong evidence of waves of uncertainty which manifest themselves as conditional heteroscedasticity. Afterwards we assess to what extent this volatility is subject to various degrees of intensity of the political conflict. For that aim, we incorporate interaction terms with dummy variables for conflict of any intensity, of markedly increased intensity and of extremely violent escalations. Residual tests indicate that the fitted models regarding the intensity variables mostly describe the data adequately.

In calm phases of the conflict without Palestinian fatalities the conditional average volatilities of weekly price returns of Israeli-produced bananas and Palestinian pears are highest. Moreover, three of the four Palestinian prices show significant responses to shocks to the price returns in the previous week which are large in magnitude. Prices of Israeli-produced commodities show reactions which are either not significant or of very small magnitude. This provides robust evidence for that prices of food of Palestinian origin are more often and more strongly impacted by prices shocks during peaceful periods while prices of food of Israeli origin tend to be more robust to such shocks.

The weekly food prices in Palestine appear to be relatively robust to varying intensities of the political conflict as measured by the number of weekly Palestinian fatalities. In weeks when the conflict caused any fatalities, the consequences for the returns of weekly prices appear to be modest. Volatility of the returns of pears and Palestinian onions are only partly impacted. For some commodities, the strength of the dynamics grows while it reduces in other cases. The intermediate conflict intensity is found to barely change volatility dynamics, while extraordinarily strong escalations only impact the conditional averages of the volatilities at small magnitude.

This analysis contributes several aspects to the literature. First, it discusses potential economic relationships between conflict intensity and food price volatility. Second, it models the effects of waves of violence on levels and volatility of food prices in the context of the Mediterranean region. Third, it constructs several variables measuring the intensity of conflict which allow a quantitative assessment of conflict impacts.

Any analysis of economic aspects of violent political conflict is severely challenged by the availability of continuous and suitably disaggregated data. As these markets are subject to political instabilities, the gathering of high frequency data for economic analysis is fundamentally challenged. The temporal and spatial scales of the data available for this analysis may conceal several effects because conflict intensity varies most strongly on a daily and a local and regional basis. Conflict-caused violence, curfews etc. are mostly local or regional events which may affect single towns and villages and their immediate surroundings. Hence, an analysis at average regional level may hide the potentially unevenly spread effects of conflict across space. Aggregation in time and across space which the weekly average prices used in this paper are based upon neutralizes short-run variation which possibly might contain important information. Further research might therefore aim to measure economic effects of conflict with temporally and regionally more disaggregated data. 
Future research ${ }^{6}$ might also aim at extending the temporal as well as the product range of the analysis. However, extending the temporal range needs continuous and consistent data gathering which would substantially benefit from establishing a transparent and publicly accessible price monitoring system as suggested by OECD (2015) or Baltussen et al. (2019). Enriching the analysis with political and trade aspects would be valuable too which depends on sufficiently available data. Last, carrying out a comparative analysis of the performance of models for improving forecasts of food price volatility, e.g., using copula-based approaches (Sokolinskiy and van Dijk, 2011; Patton, 2012), would create significant insight for stakeholders.

The results of this analysis imply limited need to establish Palestinian policies for tackling transmission of conflict-caused price shocks (as, e.g., suggested by Lacirignola et al., 2015 or Gohkan, 2018) and for managing price risks for stakeholders (as, e.g., suggested by Di Falco et al., 2014). This finding, however, only holds for the limited set of commodities considered. If future extensions of the analysis of the robustness of volatility against conflict escalations indicate substantially more susceptible commodities, then this would provide a strong justification for such policies.

\section{Acknowledgements}

The authors acknowledge the generous support of the Deutsche Forschungsgemeinschaft (DFG) for this research project as part of the project CR 95/7-1. The authors also gratefully acknowledge the very constructive help of Wassim Ghantous, Noam Preiss, Noa Tal and Suhair Abdi from B'Tselem in data gathering.

\section{References}

Akkaya S., Fiess N., Kaminski B., Raballand G., 2008. Economics of 'Policy-Induced' Fragmentation: The Costs of Closures Regime to West Bank and Gaza. World Bank Middle East and North Africa Working Paper Series No. 50, January.

Anderson K., Ivanic M., Martin W.J., 2014. Food price spikes, price insulation, and poverty. In: The economics of food price volatility, Chicago: University of Chicago Press, pp. 331-339.

Baltussen W., Drabik D., Dries L., van Galen M., Gardebroek C., Ihle R., Logatcheva K., Oosterkamp E., 2019. Monitoring of prices and margins in EU food supply chains - Existing and Alternative Approaches. JRC Technical Report JRC114719, Publications Office of the European Union, Luxembourg, DOI: $10.2760 / 197814$.

Bar Nahum Z., 2012. Demand, Competitiveness, and Regulations in the Israeli Fluid Milk Market. Contributed paper at the Second Israeli I.O. Day: "Industrial Organization, Regulation, and Competition Policy in Israel", Tel Aviv, Israel.

Bar Nahum Z., Finkelshtain I., Kan I., 2013. Estimating Political and Market Power in the Israeli Fluid Milk Market. Contributed paper at the 29th Annual Conference of the Israel Economic Association, Tel Aviv, Israel.

Blattman C., Miguel E., 2010. Civil war. Journal of Economic Literature, 48: 3-57.

Boere E., Peerlings J., Reinhard S., Kuhlman T., Heijman W., 2015. Effect of output price volatility on agricultural land use. New Medit, 14(3): 10-21.

Brümmer B., Korn O., Schlüßler K., Jamali Jaghdani T., Saucedo A., 2013. Volatility in the after crisis period - A literature review of recent empirical research. Working Paper 1, ULYSSES project, EU 7th Framework Programme, Project 312182 KBBE.2012.1.4-05, available at: http://www. fp7-ulysses.eu/.

B'Tselem, 2013. Casualty statistics. B'Tselem - The Israeli Information Center for Human Rights in the Occupied Territories, available at: http://old.btselem.org/statistics/english/Casualties.asp (accessed in January 2013).

Capitanio F., Adinolfi F., Enjolras G., Aubert M., 2014. Direct payments, crop insurance and the volatility of farm income: some evidence in France and in Italy. New Medit, 13(1): 31-40.

Cobham D., 2001. Economic Aspects of the Israeli-Palestinian Conflict: Introduction. Economic Journal, 111: 249-253.

Di Falco S., Bozzola M., Adinolfi F., Capitanio F., 2014. Crop Insurance as a Strategy for Adapting to Climate Change. Journal of Agricultural Economics 65(2): 485-504.

\footnotetext{
${ }^{6}$ We thank an anonymous reviewer for suggesting a number of these points.
} 
Diwan I., Shaban R. (eds.), 1999. Development under Adversity: The Palestinian Economy in Transition, World Bank and MAS, Washington.

Dobers G.M., Ihle R., Kachel Y., Liebe U., 2018. Economic Integration in the Middle East: Israeli-Palestinian Fresh Food Trade. Israel Affairs, DOI: 10.1080/13537121.2018.1455955.

FAO, 2011. Safeguarding Food Security in Volatile Global Markets. Edited by Adam Prakash, Rome.

García-Germán S., Morales-Opazo S., Garrido A., Demeke M., Bardají I., 2013. Literature review of impacts of food price volatility on consumers in developed and developing countries. Working Paper 2, ULYSSES project, EU 7th Framework Programme, Project 312182 KBBE.2012.1.4-05, available at: http://www.fp7-ulysses.eu/.

Gohkan C., 2018. Price volatility transmission among cereal markets. The evidences for Turkey. New Medit 17(3): 93-104.

Guillen J., Franquesa R., 2015. Price transmission and volatility along the Spanish fresh fish market chain. New Medit, 14(1): 4-11.

Hansen P.R., Lunde A., 2005. A forecast comparison of volatility models: does anything beat a GARCH(1,1)? Journal of Applied Econometrics, 20(7): 873-889.

Harvey A.C., 1989. Forecasting, structural time series models and the Kalman filter. Cambridge: Cambridge University Press.

Ihle R., Rubin O.D., 2013. Consequences of Unintended Food Policies: Food Price Dynamics Subject to the Israeli-Palestinian Conflict. Food Policy, 42: 96-105.

Jaeger D.A., Paserman M.D., 2006. Israel, the Palestinian Factions, and the Cycle of Violence. American Economic Review: Papers and Proceedings, 96(2): 45-49.

Jaeger D.A., Paserman M.D., 2008. The Cycle of Violence? An Empirical Analysis of Fatalities in the Palestinian-Israeli Conflict. American Economic Review, 98(4): 1591-1604.

Kimhi A., 2011. The role of agriculture in rural well-being: the case of Israel. New Medit, 10(2): 33-41.

Lacirignola C., Capitanio F., Adinolfi F., 2015. Food security in the Mediterranean countries. New Medit 14(4): 93-104.

OECD, 2015. Food Price Formation - 7th Food Chain Analysis Network Meeting. OECD Trade and Agriculture Directorate, Paris.

Patton A.J., 2012. A review of copula models for economic time series. Journal of Multivariate Analysis, 110: 4-18.
PCBS, 2012. Price databank. Palestinian Central Bureau of Statistics, Ramallah, Palestine.

PCBS, 2013. Atlas of Poverty in Palestine. Palestinian Central Bureau of Statistics, Ramallah, Palestine.

Rossignoli C.M., Di Iacovo F., Moruzzo R., Scarpenelli P., 2015. Dairy cattle, livelihoods and resilience in Gaza Strip: a case study. New Medit, 14(1): 24-33.

Shoshan M., Grootens J., 2010. Atlas of the conflict: Israel-Palestine. Rotterdam: 010 Publishers.

SIPRI Yearbook, 2013. Armaments, Disarmament and International Security, Stockholm International Peace Research Institute, Stockholm.

Sokolinskiy O., van Dijk D., 2011. Forecasting Volatility with Copula-Based Time Series Models, Tinbergen Institute Discussion Paper TI 2011-125/4.

Ulysses, 2014. Understanding and coping with food markets volatility towards more Stable World and EU food SystEmS. EU 7th Framework Programme, available at: http://www.fp7-ulysses.eu.

UN OCHAoPt, 2008. Increasing Need, Decreasing Access: Tightening Control on Economic Movement. United Nations Office for the Coordination of Humanitarian Affairs in the occupied Palestinian territory, Report, January 2008, East-Jerusalem.

UN OCHAoPt, 2014. United Nations Office for the Coordination of Humanitarian Affairs in the occupied Palestinian territory, available at: http://www. ochaopt.org/.

WFP, 2009. The Impact of Closure and High Food Prices on Performance of Imported Staple Foods and Vegetable and Fruits Market in the oPt. Report of the United Nations World Food Programme, Rome, Italy, December.

WFP, 2014. State of Palestine. World Food Programme, available at: http://www.wfp.org/countries/state-of-palestine/publications.

World Bank, 2008. West Bank and Gaza - The Economic Effects of Restricted Access to Land in the West Bank. Social and Economic Development Group, Finance and Private Sector Development, Middle East and North Africa Region, Washington.

World Bank, 2010. Checkpoints and Barriers Searching for Livelihoods in the West Bank and Gaza - Gender Dimensions of Economic Collapse. Sustainable Development Department, Middle East and North Africa Region, Report No.: 49699GZ, Washington.

World Bank, 2011. World Development Report 2011: Conflict, Security, and Development, Washington. 
World Bank, 2014. West Bank and Gaza, available at: http://www.worldbank.org/en/country/westbank andgaza.

Zussman A., Zussman N., 2006. Assassinations: Evaluating the Effectiveness of an Israeli Counterterror- ism Policy Using Stock Market Data. Journal of Economic Perspectives, 20: 193-206.

Zussman A., Zussman N., Nielsen M.O., 2008. Asset Market Perspectives on the Israeli-Palestinian Conflict. Economica, 75: 84-115. 